\title{
Effective reproduction number for COVID-19 in Aotearoa New Zealand
}

\author{
Rachelle N. Binny ${ }^{1,4}$, Audrey Lustig ${ }^{1,4}$, Ann Brower ${ }^{4,6}$, Shaun C. Hendy ${ }^{3,4}$, Alex James ${ }^{2,4}$, \\ Matthew Parry ${ }^{4,5}$, Michael J. Plank ${ }^{2,4}$, Nicholas Steyn ${ }^{2,3,4}$
}

1. Manaaki Whenua, Lincoln, New Zealand.

2. School of Mathematics and Statistics University of Canterbury, New Zealand.

3. Department of Physics, University of Auckland, New Zealand.

4. Te Pūnaha Matatini: the Centre for Complex Systems and Networks, New Zealand.

5. Department of Mathematics and Statistics, University of Otago, New Zealand.

6. School of Earth and Environment, University of Canterbury, New Zealand.

\begin{abstract}
The effective reproduction number, $R_{\text {eff }}$, is the average number of secondary cases infected by a primary case, a key measure of the transmission potential for a disease. Compared to many countries, New Zealand has had relatively few COVID-19 cases, many of which were caused by infections acquired overseas. This makes it difficult to use standard methods to estimate $R_{\text {eff. }}$. In this work, we use a stochastic model to simulate COVID-19 spread in New Zealand and report the values of $R_{\text {eff }}$ from simulations that gave best fit to case data. We estimate that New Zealand had an effective reproduction number $R_{\text {eff }}=1.8$ for COVID-19 transmission prior to moving into Alert Level 4 on March 252020 and that after moving into Alert level 4 this was reduced to $R_{\text {eff }}=0.35$. Our estimate $R_{\text {eff }}=1.8$ for reproduction number before Alert Level 4 , is relatively low compared to other countries. This could be due, in part, to measures put in place in early- to mid-March, including: the cancellation of mass gatherings, the isolation of international arrivals, and employees being encouraged to work from home.
\end{abstract}


medRxiv preprint doi: https://doi.org/10.1101/2020.08.10.20172320; this version posted August 11, 2020. The copyright holder for this preprint (which was not certified by peer review) is the author/funder, who has granted medRxiv a license to display the preprint in It is made available under a CC-BY-NC-ND 4.0 International license.

\section{Introduction}

As of $21^{\text {st }}$ May 2020, more than 5 million people have been infected with COVID-19 globally and over 331,000 have died. In New Zealand, border restrictions and strong interventions to maintain physical distancing (Alert Level 4) were implemented early in the outbreak (Alert Level 4 on $25^{\text {th }}$ March, with 205 cases confirmed and probable) and case numbers have remained comparatively low (1503 confirmed and probable cases; 21 deaths as of 21st May). Daily numbers of new cases have declined steadily since $5^{\text {th }}$ April and have remained below 10 since $19^{\text {th }}$ April.

Effective reproduction number, $R_{\text {eff }}$, is a key measure of transmission potential for a disease. It is the average number of secondary cases infected by a primary case. Values of $R_{\text {eff }}$ greater than one indicate a virus is likely to cause an outbreak, while values less than one mean a virus will likely die out. Global estimates place the mean basic reproduction number for COVID-19, for a fully susceptible population in the absence of any control measures, at approximately 2.6 (s.d. $=0.54$ ) (Jarvis et al. 2020). However, interventions including school closures, population-wide social distancing and case isolation, reduce $R_{\text {eff }}$ to varying degrees.

Numerous methods have been developed for estimating the reproduction number (Obadia et al. 2012). A recent study by Binny et al. (2020) used a method by Wallinga \& Lipsitch (2006) to analyse case data from 25 international locations and estimate reduction in $R_{\text {eff }}$ after strong interventions were implemented. This method calculates $R_{\text {eff }}$ by relating it to the exponential growth rate of daily new local cases via the generation time distribution (assumed to be known and to remain fixed over time). It assumes a randomly mixed population undergoing exponential growth of new local infections arising by community transmission. The method is therefore not suitable for estimation using case data from the very early stages of an outbreak, when daily numbers of new cases are low and stable exponential growth is not fully established (i.e. growth in case numbers is initially somewhat erratic).

In addition, the method cannot distinguish between imported cases (not arising by community transmission, yet still contributing to future community transmission) from local cases (arising from and contributing to community transmission). Without this distinction, and applying the method to both locally-acquired and imported cases, yields artificially elevated estimates for $R_{\text {eff }}$ because the model assumes that all new cases on a given day arose by community transmission alone. Other methods that do account for imported cases have been developed, however these also rely on suitably high case numbers (Thompson et al. 2019). New Zealand's case numbers are too low for this method to produce reliable estimates. 
medRxiv preprint doi: https://doi.org/10.1101/2020.08.10.20172320; this version posted August 11, 2020. The copyright holder for this preprint (which was not certified by peer review) is the author/funder, who has granted medRxiv a license to display the preprint in It is made available under a CC-BY-NC-ND 4.0 International license.

For these reasons, we did not apply these approaches to New Zealand case data. Instead, we use a continuous-time branching model to simulate COVID-19 spread in New Zealand (Plank et al. 2020), and report the values of $R_{\text {eff }}$ from simulations that gave best fit to case data. We present an estimate for $R_{\text {eff }}$ before and after implementation of Alert Level 4, that can be used to inform decision-making and parameter choice for models of COVID-19 spread in New Zealand.

\section{Methods}

We obtained daily case data for New Zealand from Ministry of Health, and used internationally imported cases and locally acquired cases (confirmed and probable) for fitting. The stochastic model of Plank et al. (2020) was used to simulate COVID-19 spread with the parameter values given in Table 1 (all other parameter values were as used in Plank et al., 2020). The model is a continuoustime branching process that uses the internationally imported cases as seed data and simulates the number of new clinical and sub-clinical cases transmitted within New Zealand each day. The model accounts for two broad classes of control interventions: (i) isolation of confirmed cases, reducing onward transmission; (ii) population-wide reduction in contact rates due to restrictions associated with the Alert Level system. The model allows for the delay from infection to symptom onset (Lauer et al., 2020) and from symptom onset to reporting (based on the New Zealand Data) - see Table 1. A full model description is provided in Plank et al. (2020), with extensions described in James et al. (2020) to account for individual heterogeneity in transmission rates (e.g. super-spreaders) and a proportion of clinical cases that are undetected by testing. We compared the simulated number of reported cases per day (mean of 1000 realisations) to actual reported cases and estimated best-fit values of $R_{\text {eff }}$ by minimising the root-mean-square error of square root-transformed data, over a time window from 10 March to 27 April. Bootstrap confidence intervals (95\%) were obtained by re-estimating $R_{\text {eff }}$ for each of 10,000 simulations from the best-fit model.

\section{Results}

We estimate that New Zealand had an effective reproduction number $R_{\text {eff }}=1.8[1.44,1.94]$ prior to moving into Alert Level 4; after moving into Alert level 4 this was reduced to $R_{\text {eff }}=0.35$ [0.28,0.44]. These best-fit estimates provided a good match between simulations and data, as can be visualised in Figure 1. Best-fit $R_{\text {eff }}$ estimates were relatively insensitive to changes in other model parameters, namely: the proportion of cases detected, the generation time, onset-to-isolation delay, isolation-toreporting delay, proportion of sub-clinicals and their infectiousness, relative infectiousness after isolation, and individual heterogeneity in transmission (Table 1). 
medRxiv preprint doi: https://doi.org/10.1101/2020.08.10.20172320; this version posted August 11, 2020. The copyright holder for this preprint (which was not certified by peer review) is the author/funder, who has granted medRxiv a license to display the preprint in

It is made available under a CC-BY-NC-ND 4.0 International license.

Table 1: Parameters used for model fitting and sensitivity analyses, and their sources. Reproduction number for clinical infections (no case isolation or control) was set to $R_{\text {clin }}=3$.

\begin{tabular}{|c|c|c|c|c|c|}
\hline \multirow[b]{2}{*}{ Parameter } & \multirow[b]{2}{*}{ Value } & \multirow[b]{2}{*}{ Source } & \multicolumn{3}{|c|}{ Sensitivity analyses } \\
\hline & & & Values tested & $\begin{array}{c}R_{\text {eff }} \\
\text { pre-AL4 }\end{array}$ & $\begin{array}{c}R_{\text {eff }} \\
\text { in } \mathrm{AL4}\end{array}$ \\
\hline $\begin{array}{l}\text { Distribution of } \\
\text { generation times }\end{array}$ & $\begin{array}{l}\text { Weibull }(\text { scale } \\
=5.67, \text { shape }=2.83)\end{array}$ & Feretti et al (2020) & $\begin{array}{c}\text { Wei }(\text { scale }=9.0 \\
\text { shape }=2.83), \\
\text { Wei }(\text { scale }= \\
5.67, \text { shape }=1.5)\end{array}$ & $1.6,1.75$ & $0.35,0.35$ \\
\hline $\begin{array}{l}\text { Distribution of } \\
\text { exposure to onset } \\
\text { (days) }\end{array}$ & $\begin{array}{r}\mathrm{T}_{1} \sim \Gamma(\text { shape }=5.8, \text { scale } \\
=0.95)\end{array}$ & Lauer et al (2020) & - & - & - \\
\hline $\begin{array}{l}\text { Distribution of onset to } \\
\text { isolation (days) (from } \\
\text { data) }\end{array}$ & $T_{2} \sim \operatorname{Exp}($ mean $=2.18)$ & Davies et al (2020a) & $T_{2} \sim \operatorname{Exp}($ mean $=6)$ & 1.95 & 0.05 \\
\hline $\begin{array}{l}\text { Distribution from } \\
\text { isolation to reporting }\end{array}$ & $\begin{array}{r}\Gamma(\text { shape }=1, \text { scale } \\
=3.48)\end{array}$ & Fitted to data & $\begin{array}{l}\Gamma(\text { shape }=1 \\
\text { scale }=4.70)\end{array}$ & 1.8 & 0.3 \\
\hline $\begin{array}{l}\text { Relative infectiousness } \\
\text { of subclinical cases }\end{array}$ & $R_{\text {sub }} / R_{\text {clin }}=50 \%$ & Davies et al (2020a) & $20 \%, 80 \%$ & $1.7,1.75$ & $0.4,0.35$ \\
\hline $\begin{array}{l}\text { Proportion of } \\
\text { subclinical infections }\end{array}$ & $p_{\text {sub }}=33 \%$ & $\begin{array}{l}\text { Davies et al } \\
(2020 b), \\
\text { Byambasuren et al } \\
(2020), \text { Lavezzo et } \\
\text { al (2020) }\end{array}$ & $20 \%, 50 \%$ & $1.8,1.75$ & $0.35,0.35$ \\
\hline $\begin{array}{l}\text { Relative infectiousness } \\
\text { after isolation }\end{array}$ & $c_{i s o}=65 \%$ & Davies et al (2020a) & $30 \%, 90 \%$ & $1.8,1.65$ & $0.4,0.35$ \\
\hline $\begin{array}{l}\text { Proportion of clinical } \\
\text { cases detected and } \\
\text { reported }\end{array}$ & $p_{R}=75 \%$ & $\begin{array}{l}\text { Price } \text { et al. }(2020) \\
\text { and estimated from } \\
\text { limited NZ data }\end{array}$ & $50 \%, 90 \%$ & $2,1.6$ & $0.4,0.35$ \\
\hline $\begin{array}{l}\text { Individual } \\
\text { heterogeneity in } \\
\text { transmission rate }\end{array}$ & $\begin{array}{c}Y_{K}=0.5 \text { (i.e. moderate } \\
\text { super-spreading) }\end{array}$ & $\begin{array}{l}\text { Endo et al (2020), } \\
\text { Lloyd-Smith et al } \\
\text { (2005) }\end{array}$ & $\begin{array}{l}0.1 \text { (high super- } \\
\text { spreading), } 1 \text { (low } \\
\text { super-spreading) }\end{array}$ & $1.7,1.8$ & $0.35,0.35$ \\
\hline
\end{tabular}

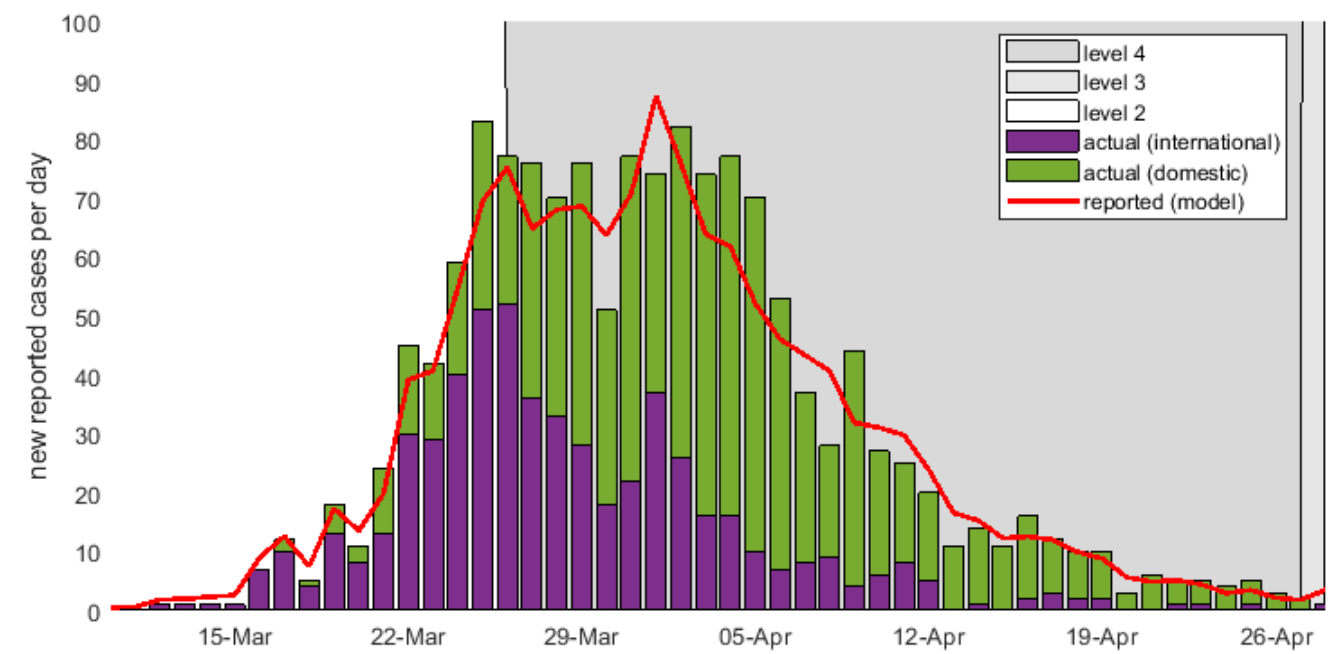

Figure 1: Simulated and actual daily numbers of new local and imported cases (confirmed and probable) in New Zealand prior to and during Alert Level 4 . The values of $R_{\text {eff }}$ that gave the best model fit to the data, evaluated using a least squares approach, were $R_{\text {eff }}=1.8$ prior to lockdown and $R_{\text {eff }}=0.35$ in Alert Level 4. 
medRxiv preprint doi: https://doi.org/10.1101/2020.08.10.20172320; this version posted August 11, 2020. The copyright holder for this preprint (which was not certified by peer review) is the author/funder, who has granted medRxiv a license to display the preprint in It is made available under a CC-BY-NC-ND 4.0 International license.

\section{Discussion}

Our results suggest that New Zealand's Alert Level 4 was effective at reducing reproduction number to a value less than one, meaning the virus was no longer likely to cause an outbreak for as long as the Alert Level remained in place. The Alert Level 4 estimate $R_{\text {eff }}=0.35$ is an especially small reproduction number and on a par with reproduction numbers reported for other countries whose Alert Level 4-equivalent interventions have been particularly effective (Binny et al., 2020). For example, lockdowns in six Australian states have successfully reduced effective reproduction number to approximately 0.3-0.5, and interventions are now being relaxed (Price et al., 2020), while other countries (e.g. UK) remain at $R_{\text {eff }} \approx 1$ (Binny et al., 2020). Our estimate for reproduction number before Alert Level 4, $R_{\text {eff }}=1.8$, is relatively low compared to those reported globally. This could be due, in part, to measures put in place in early- to mid-March, for example the cancellation of mass gatherings, fast case isolation of international imported cases, and employees being encouraged to work from home.

We estimated an $81 \%$ reduction in $R_{\text {eff }}$ (from 1.8 prior to Alert Level 4, to 0.35 in Alert Level 4) as a result of the Alert Level 4 lockdown. This is in good agreement with estimates from other recent studies, employing a range of different modelling approaches to assess effects of physical distancing on $R_{\text {eff }}$ for COVID-19. For example, Jarvis et al. 2020 reported a 74\% reduction in $R_{\text {eff }}$ (from a mean of 2.6 to 0.62 ), as a result of physical distancing during lockdown in the UK. Their approach used survey data to derive age-structured population contact matrices, to compare the mean numbers of contacts by people in different age-groups, before and during lockdown. Another study by Flaxman et al. (2020) fitted a hierarchical Bayesian model to data from 11 European countries to estimate an approximately $50 \%$ relative reduction in $R_{\text {eff }}$ due to lockdowns, compared to four other intervention policies. However, most countries the Flaxman et al. analysis were still in the early stage of outbreak; so interventions were likely not in place long enough to observe the full extent of their effect. A third study used a Bayesian SEIR-type model to infer a 78\% reduction in contacts in British Columbia due to the introduction of physical distancing measures (Anderson et al. 2020).

These estimates of reproduction number will be important for informing future decision-making on intervention policies and for improving models of COVID-19 spread in New Zealand. Since deescalating to Alert Levels 3 and 2, case numbers have been too low to obtain reliable estimates for their $R_{\text {eff }}$ using this approach. It is likely that effective reduction of $\mathrm{R}_{\text {eff }}$ under Alert Levels 2-3 after Level 4 'lockdown' will differ from the effectiveness of Alert Levels 2 and 3 before Level 4 'lockdown' on $25^{\text {th }}$ March. This is because before Level 4, there was high risk of undetected community transmission and growing numbers of local cases; whereas after Level 4 case numbers are low, case isolation is fast, and large clusters have been identified and closely monitored. 
medRxiv preprint doi: https://doi.org/10.1101/2020.08.10.20172320; this version posted August 11, 2020. The copyright holder for this preprint (which was not certified by peer review) is the author/funder, who has granted medRxiv a license to display the preprint in It is made available under a CC-BY-NC-ND 4.0 International license.

\section{R Calculator and Outbreak Simulator Tools}

To leverage the model and results described above, we built an app (http://covid19takecontrol.nectar.auckland.ac.nz/covid19_takeControl/) that allows the general public to interact with the models by 'driving' simulated Alert Level decisions and the public's response to them. COVID 19-Take Control offers a simulator for how case numbers might rise and fall with different levels of public response to Alert Levels of different lengths, an R calculator to compare the relative efficacy of different intervention tools on $R_{\text {eff }}$, and up-to-date background epidemiological and sociological information.

The app serves two purposes: 1) to communicate the models to the general public in a user-friendly and accessible way; 2) to support New Zealanders in their efforts to make huge changes to their daily lives. As its name implies, COVID 19 - Take Control is premised on prominent cognitive science findings that people are more likely to change their behaviour, even if inconvenient or costly (as lockdowns certainly are), if they feel those individual changes will be effective (Bavel et al 2020). Hence the app conveys messages of self-efficacy such as 'we are the architects of our future.' Lest those empowerment message seem trite, they are grounded in interactive tools that allow users to see the effect of their actions (in hand-washing, physical distancing, or contact-tracing) on $R_{\text {eff }}$ and on the shape of the epidemic curve. In other words, the app aims to support the general public to recognise the effects of their behaviours, that the 'power to control COVID 19 is in our hands, quite literally.'

\section{Acknowledgements}

We thank Tom Cunningham for useful discussions on effective reproduction number.

\section{References}

Anderson SC, Edwards AM, Yerlanov M, Mulberry N, Stockdale J, Iyaniwura SA, Falcao RC, Otterstatter MC, Irvine MA, Janjua NZ, Coombs D, Colijn C (22 April 2020). Estimating the impact of COVID-19 control measures using a Bayesian model of physical distancing. medRxiv 2020.04.17.20070086, doi: https://doi.org/10.1101/2020.04.17.20070086

Bavel JJV, Baicker K, Boggio PS et al (2020). Using social and behavioural science to support COVID-19 pandemic response. Nat Hum Behav, 4, 460-471, doi: https://doi.org/10.1038/s41562$\underline{020-0884-\mathrm{z}}$ 
medRxiv preprint doi: https://doi.org/10.1101/2020.08.10.20172320; this version posted August 11, 2020. The copyright holder for this preprint (which was not certified by peer review) is the author/funder, who has granted medRxiv a license to display the preprint in It is made available under a CC-BY-NC-ND 4.0 International license.

Binny RN, Hendy SC, James A, Lustig A, Plank MJ, Steyn N (6 May 2020). Effect of Alert Level 4 on effective reproduction number: review of international COVID-19 cases. medRxiv 2020.04.30.20086934, doi: https://doi.org/10.1101/2020.04.30.20086934

Byambasuren O, Cardona M, Bell K, Clark J, McLaws ML, Glasziou P (15 May 2020). Estimating the extent of true asymptomatic COVID-19 and its potential for community transmission: systematic review and meta-analysis.

medRxiv 2020.05.10.20097543, doi: https://doi.org/10.1101/2020.05.10.20097543

Davies NG, Kucharski AJ, Eggo RM, Gimma A, Edmunds WJ, CMMID COVID-19 Working Group, (2020a). Effects of non-pharmaceutical interventions on COVID-19 cases, deaths and demand for hospital services in the UK: a modelling study. The Lancet. Public Health, 5(7), e375-e385, doi: $\underline{10.1016 / \mathrm{s} 2468-2667(20) 30133-\mathrm{x}}$

Davies NG, Klepac P, Liu Y, Prem K, Jit M, CMMID COVID-19 working group, Eggo RM (2020b). Age-dependent effects in the transmission and control of COVID-19 epidemics. Nat Med, 26, 12051211, doi: https://doi.org/10.1038/s41591-020-0962-9

Endo A, Centre for the Mathematical Modelling of Infectious Diseases COVID-19 Working Group, Abbott S, Kucharski AJ, Funk S (2020). Estimating the overdispersion in COVID-19 transmission using outbreak sizes outside China. Wellcome Open Res, 5, 67, doi: https://doi.org/10.12688/wellcomeopenres.15842.1

Ferretti L, et al (2020). Quantifying SARS-CoV-2 transmission suggests epidemic control with digital contact tracing. Science, 368(6491), eabb6936, doi: https://doi.org/10.1126/science.abb6936

James A, Plank MJ, Binny RN, Hannah K, Hendy SC, Lustig A, Steyn N (15 May 2020) A structured model for COVID-19 spread: modelling age and healthcare inequities. medRxiv 2020.05.17.20104976, doi: https://doi.org/10.1101/2020.05.17.20104976

Jarvis CI, Van Zandvoort K, Gimma A, Prem K, Klepac P, Rubin GJ, Edmunds WJ (2020). Quantifying the impact of physical distance measures on the transmission of COVID-19 in the UK. BMC medicine, 18(124), 1-10. 
medRxiv preprint doi: https://doi.org/10.1101/2020.08.10.20172320; this version posted August 11, 2020. The copyright holder for this preprint (which was not certified by peer review) is the author/funder, who has granted medRxiv a license to display the preprint in It is made available under a CC-BY-NC-ND 4.0 International license.

Lauer SA, et al (2020). The incubation period of coronavirus disease 2019 (COVID-19) from publicly reported confirmed cases: estimation and application. Annals of internal medicine, 172(9), 577-582, doi: https://doi.org/10.7326/M20-0504.

Lavezzo E, Franchin E, Ciavarella C, et al (18 Apr 2020). Suppression of COVID-19 outbreak in the municipality of Vo, Italy. medRxiv 2020.04.17.20053157, doi:

https://doi.org/10.1101/2020.04.17.20053157

Lloyd-Smith JO, Schreiber SJ, Kopp PE, Getz WM (2005). Superspreading and the effect of individual variation on disease emergence. Nature, 438(7066), 355-359.

Ministry of Health (2020). COVID-19 - current cases details. Available from:

https://www.health.govt.nz/our-work/diseases-and-conditions/covid-19-novel-coronavirus/covid-19current-situation/covid-19-current-cases/covid-19-current-cases-details (Accessed 12 May 2020).

Obadia T, Haneef R, Boëlle PY (2012). The R0 package: a toolbox to estimate reproduction numbers for epidemic outbreaks. BMC medical informatics and decision making, 12(1), 147.

Plank MJ, Binny RN, Hendy SC, Lustig A, James A, Steyn N (9 April 2020). A stochastic model for COVID-19 spread and the effects of Alert Level 4 in Aotearoa New Zealand. medRxiv 2020.04.08.20058743, doi: https://doi.org/10.1101/2020.04.08.20058743

Price DJ, Shearer FM, Meehan MT, McBryde E, Moss R, Golding N, Conway EJ, Dawson P, Cromer D, Wood J, Abbott S, McVernon J, McCaw JM (30 April 2020). Early analysis of the Australian COVID-19 epidemic. medRxiv 2020.04.25.20080127, doi: https://doi.org/10.1101/2020.04.25.20080127

World Health Organisation (11 May 2020). Coronavirus disease (COVID-19) Situation report 112. Available from: https://www.who.int/docs/default-source/coronaviruse/situation-reports/20200511covid-19-sitrep-112.pdf?sfvrsn=813f2669 2 (accessed 12 May 2020)

Wallinga J \& Lipsitch M (2006). How generation intervals shape the relationship between growth rates and reproductive numbers. Proceedings of the Royal Society B: Biological Sciences, 274, $599 \mathrm{e} 604$. 